\title{
The tradition-historical setting of Psalm 25: How wisdom motives contribute to its understanding
}

D J Human

\section{ABSTRACT}

The tradition-historical setting of Psalm 25: How wisdom motives contribute to its understanding

Psalm 25 is an acrostic psalm and an individual lament. Several traditionhistorical motives and allusions can be identified in this text. Especially a few motives and images from the Old Testament wisdom literature contribute to the significance of the psalm. These motives are being identified and their function being determined in the context of the psalm as a whole. They are interwoven with other identified traditions and motives to contribute to the psalm's understanding.

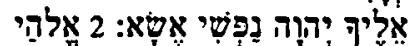

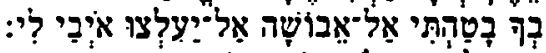

3

4

5

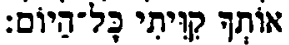

6

7

ירוֹ:

8

9

10

11

12

13

14

15

16

17 


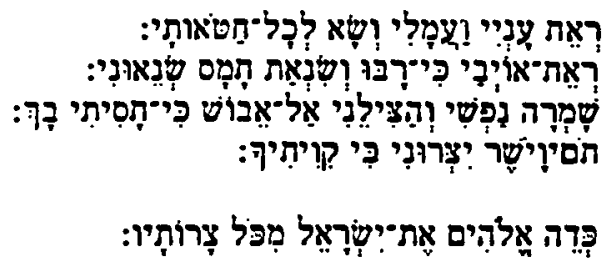

\section{INTRODUCTION}

In a praise song of the Qumran congregation', the hymn of Paul Gerhardt, Nach Dir, $O$ Herr verlanger mich ${ }^{2}$ and several other musical settings ${ }^{3}$, we find the lyrical resonance of the contents from Psalm 25. These echoing sounds reflect phrases and formulas of a prayer, which contains expressions of hope and confidence as well as utterances of expectation and praise. This psalm became a stronghold for the faithful supplicant in distressful situations through the ages.

Psalm 25 expresses the reflections and petitions of a pious man who is threatened by the conduct of his enemy, by the reality of his own sins and by a situation of utmost distress. Despite a discouragement and dejected-ness, the psalmist casts his hope on Yahweh-Elohim for instruction, guidance and forgiveness. He longs for a life in harmony with God, his Saviour (5a).

The psalm is a literary artefact with an alphabetical acrostic structure as the most prominent feature. This framework is constructed with a mosaic of limited words and expressions. Typical of the acrosticon, the tendency becomes visible where definite sounds, keywords and phrases are repeated. Although exegetes describe this literary characteristic different$1 y^{4}$, they all identify the same figure of speech, namely, repetition.

The acrosticon, which probably belongs to the poetry of the postexilic wisdom schools, contributes not only to the decorative character of this psalm, but stresses the non-oral function of the text. It thus means that this form of art would have rather caressed the eye of the reader than his ear. Psalm 25 is in this regard no exception.

The text exhibits further particular relations with Psalm 34. Schilden-berger" refer to these two psalms as "Zwillinge". It was especially Ruppert ${ }^{7}$, who, due to similar prayer descriptions and wisdom imprinted allusions, alleged the dependence of Psalm 25 on the wisdom psalm, Psalm 37. With recognition of mutual relations, Lohfink convincingly turned this thesis of the dependence of Psalm 25 on either Psalm 34 or Psalm 37 down. He concludes that "Psalm 25 sei von einem 
der beiden Psalmen abhängig oder einer von ihnen von Psalm 25". Other psalms which exegetes relate to Psalm 25, are Psalms 86,119 and 143. Hossfeld has added psalms $44,78,103$ and 132 to this list.

The research history on the text analysis of Psalm 25 brings a variety of approaches to the surface. This includes a structural-strophic analysis; 10 exposition by means of numerical-geometric techniques; 11 a metrical statistic approach ${ }^{12}$; and finally a redactional approach ${ }^{13}$ where Psalm 25 forms part of a larger redactional collection.

The question on the main theme of the psalm stimulates exegetes to make different observations. Ruppert ${ }^{14}$ stresses the issue of hope, while Van Uchelen 15 describes the core of the contents as God who is instructing his ways. The central theme for Hossfeld 16 is the forgiving of sins, while the lengthy description of Ridderbos ${ }^{17}$ portrays the psalm as a prayer for deliverance, guidance and forgiveness. The identification of seven themes or semantic categories by Lohfink ${ }^{18}$ confirms that the central theme of Psalm 25 cannot be confined to a single category or denominator.

The relationship between the different tradition historical motives and allusions is a vivid and debatable issue in the research history of Psalm 25 . This aspect will receive special attention in the following exposition.

\section{STRUCTURE}

Regarding both its form and context, this psalm exposes an own distinctive and independent character. Ruppert ${ }^{19}$ formulates the thesis that Psalm 25 is a "literarische Komposition" with a palyndromic chiastic structure of which verse 11 forms the centre and focal point. This parallelistic and chiastic composition was first demonstrated by Möller ${ }^{20}$ on which Lohfink ${ }^{21}$ builds forth.

The structure of Psalm 25 cannot be captured in a single or final depiction. The text reflects a variety which opens the possibility for several angles of incidence. The psalm notwithstanding forms a demarcated unit which can be divided into three strophes and an epilogue. It includes the following:
A 1-7 - An opening prayer
B 8-14 - Expressions of confidence
8-10 - Exposition of the being and conduct of Yahweh
11 - Prayer for forgiveness
12-14 - Description and position of the "godfearing" believer's relationship with Yahweh




\section{15-21 - A closing prayer and petitions \\ *22 - Epilogue.}

This structure is suggested by several exegetes 22 , while interpretation differences amongst others mainly centre around the division between strophes B and C or the structural position of verse 22. Some scholars regard verse 15 as part of strophe $B^{23}$, while others see it as an introduction to the final prayer in strophe $\mathrm{C}$.

Verses 1-7 form a prayer, through which the suppliant asks God for deliverance, guidance and forgiveness. Strophe B (8-14) consists of three parts. Verses 8-10 describe the being and acts of God. He is made known by a description of attributes. Verse 11 is a prayer for forgiveness, while 12-14 depicts the godfearing man in this relationship to Yahweh. As a nexus or bridge verse, verse 15 introduces strophe $C$ with an atmosphere of expectation, hope and prayer. In the epilogue, verse 22 , the individual experience of the psalmist is collectified and applied to Israel, who is symbol of either the congregation or the nation.

\section{LITERARY GENRE}

With little exception, scholars typify the literary genre or Galtung of Psalm 25 as an individual lament ${ }^{24}$. The text exposes elements such as the lament $(6,7,16-19)$, prayer and petition $(1-7,15-22)$, hope and trust $(2-3,5,8,20-21)$ confession of $\sin (7,11)$ and confidence $(15)$ as well as hymnic descriptions $(5,8-10)$. Even the 22-verse-structure is typical of the so called lament 25 .

The predominant prayer character convince researchers to describe the psalm as a spiritual prayer ${ }^{26}$, as "ein Gebetslied" 27 or as a "prayer of the congregation" 28 . The fact that the prayer with the wishes and petitions is not the only formgeschichtliche element in Psalm 25, restrains these characterisations from being descriptive for the psalm as a whole. To typify the text as a "prayer of the congregation" alone would likewise not be satisfactory, since the psalm functioned (and could probably still function) in the first instance as the experience of the individual (1-21) and was then on a second level of interpretation applied to the collective experience of Israel - due to a possible later addition of verse 22 .

Although Lohfink" is of the opinion that "Psalm 25 hat auf Gattungsebene mit weiter entwickelten Gestalten von Klage - und Dankliedern zu tun", he classifies this text like Psalms 15 and 24 - under the "Einlaßliturgie der Völkerwallfahrt". This means that the psalm functioned as a prayer for those people who want to enter the sanctuary at Zion or for 
the nations who will gather at mount Zion in escatological times. Again, the element of prayer is predominantly stressed.

The prominent accurrance of teaching and wisdom elements in Psalm 25 convince other exegetes to typify it forngeschichtlich as a didactic $^{30}$ or wisdom psalm ${ }^{31}$. The fact that these elements do not play a sole or the major role if the Psalm makes these descriptions as overarching classifications for the whole psalm unsatisfactory. They are rather indications of a definite function in the Wirkungsgeschichte of the psalm.

The dilemma to unite all the different formgeschichlliche elements of the psalm under the one denominator, namely an individual lament, is rather a provisional solution. Since it cannot nuance them all simultaneously.

The emphasis should rather be placed on the coherence and function of the different Gatrungelements. It is of importance to notice that the combination of these genre elements develope a comforting function. During the distressful circumstances, stimulated by the misery of the enemy, his affliction and own sins, the psalmist bewails his situation before God in the laments $(6,7,16-18)$ as well as in prayer and petitions $(1-7,15$ 22). His utterances include expressions of hope and trust $(2-3,5,8,20-21)$, hymnical descriptions $(5,8-10)$ and confessions of $\sin (7,11)$ and trust $(15)$. The author's strategical and decorative placement of the individual's experience within the framework of his trust expressions (2-3, 20-21), adds a theological dimension to the psalm's semantic interpretation. With an inclusion, the psalmist's experience is thus formgeschichtlich embraced by his trust and confidence in the God, who assures redemption and deliverance (5). To seek refuge with God means comfort and security for everyone who finds him- or herself in situations of distress - also for Israel (22).

With the above mentioned elements being discussed, full attention can now be paid to the tradition-historical setting and composition of Psalm 25.

\section{TRADITION-HISTORICAL SETTING}

It is tradirionsgeschichtlich very difficult to identify a definite salvation historical tradition in Psalm 25. The author nevertheless paints the portrait of his text with allusive language, which is familiar to the Old Testament.

Terminology and motives from the Pentateuch are evident. Especially the language from Exodus 32-34 and salvation historical expressions from Deuteronomy and the so-called Deuteronomist become visible. Themes from the cult and typical prayer expressions from the psalms are 
also used by the psalmist. The text doesn't even escape the influence of the Old Testament wisdom school. A single prophetical motive, which occur regularly in the psalms also shows up in Psalm 25.

The language of the respective tradition historical motives and allusions are intertwined and confirm the independent style and intention of the author. Although he uses phrases and terminology with specific meaning and content, they function unique in the given context of Psalm 25. Every term and expression reflects an own significance, due to its relationship with other phrases and motives in the psalm.

Terminology from the Pentateuch exhibit reflections from Exodus 32-34, from the book of Deuteronomy as well as from the so called Deuteronomist. Motives which can be identified from Exodus 32-34, are the following: 1) The renewal of Yahweh's brrit with Israel at Sinai (Ps 25:10,14 = Ex 32:15; 33:10,27-29) 2) God's goodness (Ps 25:7,8,13= Ex 33:19) which becomes visible through his steadfast love and faithfulness (Ps 25:6,7,10 = Ex 34:6-7), his grace (Ps 25:16 = Ex $33: 13,16,19 ; 34: 6,9)$ and mercy (Ps 25:6 = Ex 33:19;34:6; 3) the theme of sin forgiving (Ps 25:7,8,11,18 = Ex 34:7,9); 4) Yahweh's path's and ways and how he makes them known (Ps 25:4,5,8,9,12,14 = Ex 32:8; $33: 1$; 103:7; 67:3); 5) The use of other single terms like 2ר (Ps 25:11= Ex 34:6), נצר (Ps 25:10 = Ex 34:7), ובר (Ps 25:20 = Ex 34:11), 25:6,7 = Ex 32:13) and $\times$ ' (Ps 25:15,17 = Ex 32:11,12) in the semantic fields of the above mentioned motives, would confirm the hypothesis that the psalmist knew the text of Exodus 32-34 while composing Psalm 25. He probably overtook motives from these texts to reconstruct his own independent text with its own meaning and content.

To confirm this possible influence of Exodus 34 on Psalm 25, one could further state that Exodus 34, like Psalm 25, is the only Old Testament text where the terms עדוּ (10), (10,14) and (10) appear together.

As a continuation of his promises to the patriarchs and especially the content of his berit with Abraham (Gen 12:7; 13:15; 15:18; 17:8 etc), Yahweh promised his people, Israel, to be a God for them. This undertaking rested on two pillars, namely that He would lead them out of their misery and distress from Egypt (Ex 6:48; Dt 4:20; 7:8; Jdg 12:18) and that $\mathrm{He}$ will bring them and their children into the promised land which they will possess (Ex 6:6-7; Dt 1:8; 4:1; 8:1; Ps 44:4; 105:44 etc).

The question could indeed be raised whether the psalmist overtook these heilsgeschichtliche motives and allusions from the Sinai berit or had them in mind when formulating $13 \mathrm{~b}$ ("and his children shall possess the 
land"), the metaphor in $15 \mathrm{~b}$ ("for he will lead my feet out of the net") and in $17 \mathrm{~b}$ ("he will lead me out of my distresses"). Given the assumption that the author utilized these allusions when constructing the text of Psalm 25 with its own context and content, this conclusion is quite possible. Against the background of the Israelite salvation history, these motives function to establish the redemptive and blessing acts of Yahweh (Dt 11:22; 19:9; 26:17; 28:9; 30:16; Jdg 2:22; cf Ps 25:13 = Ps 37:9,11,12,29,34).

To walk on God's way, is a well known motif, which occurs in Deuteronomy and the so-called Deuteronomist (Dt 11:22; 19:9; 26:17; $28: 9 ; 30: 16 ; \mathrm{Jdg} 2: 22$ ). It even becomes a prerequisite for the reception of Yahweh's goodness, namely, to take the land in possession (Dt 5:33). He who walks on God's ways, is someone who really fears Him (Dt 8:6; 10:12).

Despite its occurrence in Exodus 34:9, the theme of sin forgiving also appears in the Pentateuch (Num 14:19) and the Deuteronomist (Dt $29: 19 ; 1 \mathrm{Kg} \mathrm{8:30)}$ ). The theme forms the focal point and centre of the psalm and is the nexus between verses $8-10$ and $12-14$. It forms an angle of incidence as well as the turning point of the psalm.

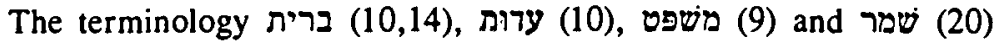
are all well known salvation historical concepts which appear in the Pentateuch and the Deuteronomist ${ }^{32}$. The connection between נצרית and

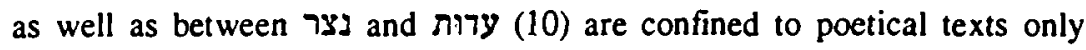
(Dt 33:9; Ps 119:2,22,129).

The hendiadys הסד ואמת (10), which probably functioned as a liturgical formular ${ }^{33}$, is also familiar to the text of Exodus 34:6. Although Ton appears quite regular in the psalms, its connection with berit in Deuteronomy 7:9,12 exhibits that the concept should primarily be understood against the background of the Sinai-berit. Describing the quality of God's relationship with man, the term expresses the "gemeinshaftgemäße Verhaltungsweise Gottes der Seinen gegenüber ${ }^{34}$.

These heilsgeschichtliche motives and terms confirm the special relationship between Psalm 25 and the salvation history of Israel, as described in the Pentateuch and the Deuteronomist. The function of these allusions and terminology could be summarised as follows:

* They serve in the first instance as a recognition of and confidence in the salvation power and faithfulness of Yahweh in the past;

* Secondly, they allude to a remembrance of the contents and responsibilities of the Sinai-berit between Yahweh and his people. It becomes 
a measurement for hope and expectation in times of distress and confirms the assurance that God will redeem his berit-partner.

* Lastly they acquaint the reader with the quality and content of a godfearing and devoted God-man relationship, as become known through the language and motives of the Sinai-berit.

Motives and images from the Israelite wisdom theology tend to show an influence on Psalm 25. The way or path-metaphor, the several teaching motives as well as aspects of the retribution doctrine make the influence of this tradition known in the text. In reaction on Ruppert, it was especially the work of Lohfink ${ }^{35}$ and Hossfeld ${ }^{36}$ which defined the relationship between the wisdom literature and the psalm.

The metaphor of the path or the way $(4,5,8,9)$ which indicates a life of faithfulness or unfaithfulness to Yahweh, is prominent in the Israelite wisdom literature (Prov 1:12; 2:8,12 etc). Kittel ${ }^{37}$ found it therefore not strange to typify the prayers for God's guidance in the psalm as wisdom proverbs.

The teaching motif plays a central role in verses $4,5,8,9$ and 12 . Teaching has the intention to educate someone in order to get him realise what is right and wrong in God's eyes. This wisdom brings insight and results in a happy and prosperous life on God's way. Although man plays an important role in the teaching process, he is not the focal point of it.

Wisdom education in the Old Testament aims to say who Yahweh is as well as what $\mathrm{He}$ does and says. It teaches man how to relate with God or how to react to this deeds of deliverance. This pattern could well be identified in verses 8-14.

טוב ויنיר (8) is a hymnic characterisation of Yahweh (Pss 16:2; 34:9; $106: 1 ; 107: 1 ; 118: 1 ; 119: 68 ; 135: 3 \mathrm{etc})$. He is the wisdom teacher who not only instructs sinners and guides the humble (8), but also shows the godfearing man his ways (12). Through this teaching, man finds exposure to Gods ways. Thus, through the experience of God's goodness which finds access to people's lives by means of instruction, the godfearing man experiences Gods spendour (Ex 33:18-19).

The guidance and instruction of Yahweh as well as His 70n-attitude contribute to the suppliant's confession that God is good (8). Where other Old Testament texts only combine his goodness to a 70n-attitude (Pss $100: 5 ; 106: 1 ; 107: 1 ; 118: 1,29 ; 136: 1$ ) or to a teaching motive (Ps 119:68), both these elements merge in Yahweh's goodness. טוב therefore exposes the spendour of God in this distressful situation and anticipates deliverance. 
After being instructed by God, man has a choice on which road to travel (Ps 119:30,173]). The afflicted individual clearly expresses his affinity for the way where he is accompanied and directed by Yahweh. He who chooses this way has a distinctive profile. Who is this man (12)? He is a man who fears God (Prov $1: 7 ; 3: 7 ; 14: 2,16$ ). He will experience the blessing consequences of prosperity, happiness and relief. He will enjoy God's טוב (Ps 31:20). Verses 13-14 follow the structure of the Israelite wisdom tradition by explaining 20 explicitly.

Characteristics of the Israelite retribution principle, as being exposed in the Tun-Ergehen Zusammenhang, becomes visible in the psalm. Good conduct is blessed by prosperity, while catastrophe follows bad behaviour.

He who trusts in God, will not be put to shame $(2,3,20)$. He will experience deliverance and refuge. The unfaithful (3) on the other hand, will be put to shame. Those who keep God's covenant and testimonies, will experience Lord. The godfearing will overnight in goodness, his children will possess the land and he shall enjoy the intimacy of a relationship with Yahweh (1314). The psalm concludes with the hope with which it starts. The assurance is given in verse 21 that is a typical expression of the wisdom literature, which phrase the rullness or completeness of a relationship with God (Job $1: 1,8 ; 2: 3 ; \mathrm{Kg}$ 9:4: Ps 37:37).

Similarities and particular relationships between Psalm 25 and other well known wisdom psalms, 34 and 37, confirm the influences of Israelite wisdom thought and motives on the psalm. These motives however function independently in the own context of Psalm 25.

The function of these wisdom allusions and motives can be reduced to the following:-

* Firstly, they expose a didactic intention. To the reader is made known what wisdom is, namely that those who go on God's way could reckon with deliverance. This create hope for the supplicant in any distressful situation.

* Secondly they have a hymnic function. With different expressions of praise (7b, 8-10, 1la $\alpha$ ) Yahweh is exulted for his goodness. He is praised, for in this praise, his love and realized deliverance for the afflicted is anticipated. This strengthens the hope and trust in God for those people who are afflicted by circumstances. 
Elements and expressions from the cultic tradition similarly draw attention. Especially prayer formulations are prominent. They include: “To you, Yahweh I lift up myself" (verse $1=$ Pss 24:4; 143:8), "Remember" (verses $6,7=$ Pss $74: 2,18,22 ; 89: 42 ; 119: 49 ; 132: 1 ; 137: 7$ etc), "Turn you to me" (verse $16=$ Pss $34: 17 ; 86: 16 ; 119: 152$ ), "be gracious to me" (verse $16=$ Pss 4:2; 6:3; 9:14; 26:11; 27:7 etc), "Guard my life" (verse $20=$ Pss $16: 4 ; 17: 8 ; 86: 2 ; 140: 5 ; 141: 9$ ) and "preserve me" (verse $20=$ Pss $7: 2 ; 22: 21 ; 31: 3,16 ; 39: 9$ etc). These utterances not only strengthen the atmosphere of petition, but confirm in a functional way the dependence of the suppliant on Yahweh.

Other cultic motives or allusions which play a central role in the psalm are the piety of the "ע ("the poor" or "the humble" - verses $9,16,18)^{38}$. The עy istressed and overpowered by the enemy (verses $2,19=$ Pss $3: 3 ; 38: 20 ; 119: 157)^{39}$. His distress and misery as well as his sin and guilt $(7,11,18)$ which are brought before God, are typical themes belonging to the cult ${ }^{40}$.

No relationship with God is complete without the call upon His Name. With such an utterance, the psalm starts (1). שמען (11) is a familiar expression in the Psalter (Pss 23:3; $31: 4 ; 106: 8 ; 109: 2 ; 148: 5,13$ ) to incline the identity and presence of Yahweh ${ }^{41}$. The cult was the Sitz where God's Name, the theolegomenon of his presence was experienced in a special way. For the sake of His Name, the psalmist asks for forgiveness (11).

The concept נוש $(2,3,20)$ was probably overtaken by the cult from the prophetical sphere42. It is an important motive in the prophetical salvation and doom oracles. When Stolz describes בוש he says: "das was Jahwes Willen zuwiderläuft, muß zunichte werden". This destruction finds realization in the בוש-happening (Is $1: 29 ; 19: 9 ; 45: 17,24 ; 54: 4$ etc). Therefore the psalmist prays that he should not be put to shame, but that his enemy should experience this disgrace.

It is clear that these cultic motives contribute to the portrayal of the suppliant's relationship with God. The intensity and the quality of this relationship is nuanced by these motives. His pain and praise, his hope and trust are all carried by cultic expressions, motives and allusions.

\section{CONCLUSION}

Psalm 25 is a fine decorated work of art with content and literary features in its own right. The use and positioning of keywords and traditionsgeschichtliche motives and allusions contribute to the calculated 
composition of this psalm, which is not "simply a conglomeration" of a few loose thoughts and terms ${ }^{43}$. The decorative style not only serves an aesthetic purpose, but has an emphatical function to stress the content. It draws the attention to certain focal points in the text.

Regarding the tradition historical elements, the psalm reflects an interwovenness of motives, images and allusions from the Old Testament literature. Themes and expressions from the cult are not only intertwined with elements of the wisdom tradition, but salvation historical allusions and elements from the Pentateuch and the Deuteronomist are also melted with them. With motives from the Law, the Prophets and the Writings, Psalm 25 indeed exposes a canonical profile.

\section{NOTES:}

1 E Lohse, Die Texte aus Qumran, München 1971, 125.

2 E von Cranach-Sichar, Wach auf mein Herz - die Lieder von Paul Gerhardt, München 1949, 103.

3 T Wittstruck, The Book of Psalms: an annotated bibliography, New York 1994, 594.

4 Eg C A Briggs \& E G Briggs, A critical and exegetical commentary on the book of Psalms, Edinburgh 1906, 221... stairlike parallelism; P C Craigie, Psalms I50 (WBC), Texas 1983, 216... repetitive style; N H Ridderbos, Die Psalmen Stilistische Verfahren und Aufbau mit besonderer Berücksichtigung von Ps I-4I, Berlin 1972, 201... Stufenrythmus; H Möller, "Strophenbau der Psalmen", $Z A W 50$ (1932), 243,250... Verstesponsion, Strophenresponsion and Parallelismus stropharum.

$5 \quad$ A Deissler, Die Psalmen, Düsseldorf 1964, 104.

6 J Schildenberger, “Das Psalmpaar 25 \& 34. Bitte und Dank", Erbe und Auftrag $57 / 4$ (1981), 270.

7 L Ruppert, "Psalm 25 und die Grenze kultorientienter Psalmenexegese", ZAW 84 (1972), 577.

8 N Lohfink, “Lexeme und Lexemgruppen in Psalm 25", in: W Groß, H Irsigler \& T Seidl (Hrsg), Text, Methode und Grammatik (Festschrift W Richter), St Ottilien 1991a, 293,295.

9 F L Hossfeld, "Bundestheologie der Psalter", in: E Zenger (Hrsg), Der Neue Bund im Alten, Freiburg 1993, 162. 
11 J Bazak, "Structural geometric patterns in Biblical poetry", Poetics Today 6 (1985), 475-502 and "Numerical devices in Biblical poetry", VT 38 (1988), 332-337.

12 D N Freedman, "Acrostics and metrics in Hebrew poetry", Harvard Theological Review 65 (1972), 367-392.

13 N Lohfink, "Der Neue Bund und die Völker", Kirche und lsrael 6 (1991b), 115-133.

14 Ruppert, op cit, 577.

15 N A van Uchelen, Psalmen deel l (l-40), Nijkerk 1979, 170.

16 Hossfeld, op cit, 162.

17 Ridderbos, op cir, 200.

18 Lohfink, op cit, 1991, 281 describes the categories as follows: (1) God's way(s) and instruction; 2) covenant and law; 3) sin and forgiving; 4) misery and piety; 5) confidence and hope; 6) enemy and deliverance; 7) God's attribute's and conduct.

19 Ruppert, op cit, 576.

20 Möller, op cir, 243.

$21 \quad$ N Lohfink, op cit, (1991b), 115-133.

22 Briggs \& Briggs, op cit, 219; E J Kissane, The Book of Psalms, Dublin 1966, 110; A A Anderson, The Book of Psalms, London 1972, 207; Schildenberger, op cir, 270; H J Kraus, Psalmen (BKAT XV/I), Neukirchen 1978, 209; Craigie, op cir, 218.

23 Möller, op cit, 244; Ridderbos, op cit, 200; W S Scroggie, The Psalins, London 1978, 156 and Lohfink, op cir, 1991b, 115-133.

24 J Ridderbos, De Psalmen, Kampen 1955, 217; Deissler, op cir, 104; H Gunkel, Einleitung in die Psalmen. Die Gattungen der religiosen Lyrik Israels, Göttingen 1968, 106; Anderson, op cit, 206; J P M van der Ploeg, Psalmen, Roermond 1973, 170; Kraus, op cit, 209; G Anderson, "Sicut Cervus" : Evidence in the Psalter of Private Devotion in Ancient Israel", Vetus Testamentum 30 (1980), 393.

W G E Watson, Classical Hebrew poetry. A guide to its techniques, Sheffield $1984,199$. 
26 M Buttenwieser, The Psalms, Chicago 1938, 809.

27 Kraus, op cit, 209.

$28 \quad$ Briggs \& Briggs, op cit, 219; Ruppert, op cit, 582.

$29 \quad$ Lohfink, op cit, 1991 a, 293.

30 Kissane, op cit, xvi.

31 H D PreuB, Einführung in die altrestamentliche Weisheitsliteratur, Stuttgart $1987,164$.

32 E Kutsch, "Berit. Verpflichtung", in: E Jenni \& C Westermann (Hrsg), THAT II, (1971), 341; see Exodus 21:1; Leviticus 26:46; Deutoronomy 4:1; 6:1 etc.

33 J Scharbart, "Formgeschichte und Exegese von Ex 34,6ff. und seiner Parallelen", Biblica 38 (1957), 130.

34 N Glueck, Das Wort Haesaed in altrestamentlichen Sprachgebrauch als menschliche und gatrliche gemeinschaftsgemaße Verhaltungsweise (BZAW 47), Gießen 1927, 66.

35 Lohfink, op cit, 1991a, 295.

36 F L Hossfeld, "Bundestheologie der Psalter", in: Zenger, op cit, 169-176.

37 R Kittel, Die Psalmen übersetzt und erklät (KAT XIII), Leipzig 61929, 99.

38 Kraus, op cit, 108; H J Kraus, Theologie der Psalmen. BKAT XV/lll, Neukirchen 1979, 188.

39 Kraus, op cit, 1978, 112; Kraus, op cit, 1979, 156; Keel, op cit, 163.

40 Cf for יחיד Psalms 22:21; 35:17; 68:7; for צsalms 31:8; 34:7,18; 54:9; 77:3; 86:7; 120:1; 143:11 etc; for pis Psalm 107:6,13,19,28; Jobe 15:24; for י ראה Psalms 9:14; (31:8); 119:153; for תxטח Psalms 32:5; 38:4,19; 79:9; 103:10; for yטכ Psalms 39:9; 51:3,5; 103:12; for 9 Psalms 18:24; 31:11; $51: 4 ; 103: 3 ; 130: 3,8$ etc.

$41 \quad$ Kraus, op cit, 1979, 21.

42 O Keel, Feinde und Gottesleugner, (SBM 7), Stuttgart 1969, 162; F Stol2, "Di - bos: zuschanden werden", in: E Jenni \& C Westermann (Hrsg), THAT I (1984), 272.

43 Watson, op cit, 183. 